\title{
技術報告 精紡々出張力のチェース変位による特性
}

\section{1.まえがき}

そ毛精紡幾の高速化は数年来着実に進められて和り， すでに $30 \sim 40 \%$ のスピードアップが達成されている. このさきまだまだスピンドル回転数は上昇をとげるであ ろろが，この高速化の方何は大きく 2 つに分けて考えら れる、すなわち1つはこれまでのよ5にバルーンを形成 させながらかなり高い紡出張力のもとで高速化を゙進めて いくものであり，1つはいままでの概念にとらわれない 新しい紡績法を採用することで，バルーンを形成させず にきわめて低い張力のもとで高速化をはかるものであ る。前者に拈手段としてはコニカルリング，バル ーンコントロールリング, スピンドル回転の自動変速 装置の採用などがあり，現在までの高速化はこれらに負 らところが大きい，後者の例としてはまだ試験研究の段 階にあるものも含めてたとえば頭よりスピンドル（バル ーンを積極的に崩壊させたまま紡出するもの), ポット 精紡㙨などがあり大幅な回転上昇をねらっている.

バルーンを形成させない新方法の研究はもちろん進め 襍ならないが，工場技術者としては前者の方问で一層 の高速化をはかるのが急務である. アンチノードリン グ，コニカルリングを使用して高速化は相当達成され るがリングレールが上昇したとき(コップへの巻取角 度が最小の近くで）張力の増大はさけられないので, こ れ変速装置を゙加えて変速運転の最適条件を求めた。上 記のようにアンチノード リング, コニカル リングの種 類, 設置条件によらず張力の増大の現象はつね生ずる からこ礼を極力持さえるよう最適条件を独立に求めるこ とができる。

\section{2. 変速運転について}

変速運転といら考え方はけっして新しいものでない が，その装置としては紡出張力を測定し，この結果と基

会員村 上 文 男***
" 礒 部 洋 一 郎

準張力との比較を行なって回転を変化させてやるフィ一 ドバック方式が望ましいが第 2 䚽のようなプログラム コントロール方式が実際的である.フィードバック方 式では経済的にひさあわないことのほかにあとでのべる ように張力が最大になったときにスピンドルの回転を最 低にすることの困難な場合が生ずる欠点をもつからであ る.

変速様式にはベース変速 (リングレールの平均位置 すなわちコップの形成過程に応じて変速させるもの), チェース変速（コップのチェース位置すなわちリング レールの昇降 1 回ごとに変速させるもの), さらにこれ ら 2 者を組み合わせたものの 3 様式が考えられる.コッ プ形成の初期に颃いてはストレッチ（スネールワイヤ からリングまでの距離）が大であり，バルーンが大きく なって必然的に紡出張力は高くなる．とくにコップ尻形 成中は巻取角度が小さいので張力は著しく高くなり系切 れの集中的発生の挔れがある。

したがってこの期間だけスピンドル回転を若干低下さ せ、コップ尻が完成したあとスピードアップして平均 スピンドル回転を稼ぐのがいわゆるべース変速である。 コップ尻が完成したあとスピードアップするとこんど はリングレールの昇降運動に応じてすなわち巻取角度 の大小に応じて紡出張力は周期的変動を示す．とくにリ ング レールが上昇し，チェースの上部を巻くときは巻 取角度が小となり張力はこの前後に和いて異常に高くな る.したがってチェース位置に応じてスピンドル回転数 を変化させればこの張力の異常高をさけることができて 糸切れを減少させることができるし，また糸切率を同一 水準におくならば一層の高速化が可能である。これがチ ェース変速である. 増速およびチェース変速開始後リン グレール下降位置に打いてバルーンくずれが発生し， これが糸切れ原因に大きく関連する場合は開始時期を特 くらせればよく，本試験に括いては 3 分玉以降に実施し

* The Effect of Ring Rail Position on Spinning Tension.

** F. Murakami, Y. Isobe, Member. 集洋紡績株式会社 


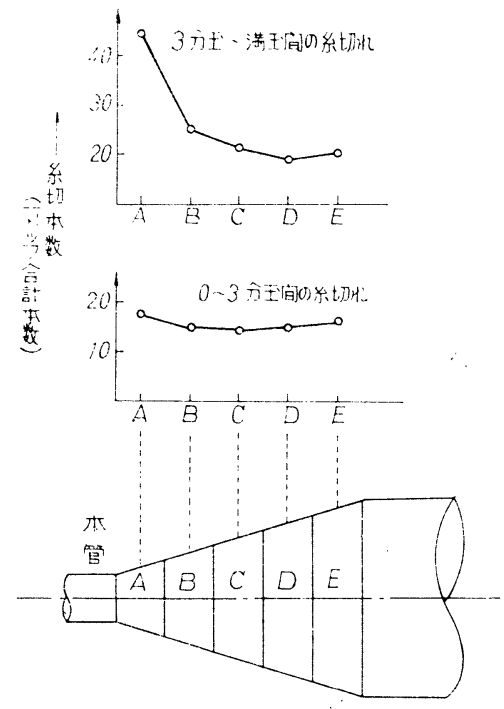

（第 1 図）千ェース位置と系切本数

た.われわれが数年前にエクスランスフ混紡 $(40 / 1)$ について測定したチェース位置（ $A \sim E$ の 5 区分）と系 切数との関係を第 1 図に示す.チェース上部の $A$ に扣い て巻取角度の関係から糸切れが圧倒的に多いことがわか るが, チェース変速によりこの部分の糸切れを減少させ らることが期待できる.

このようにチェース位置による張力変動の幅をできる だけ小さくし，ベース変速とともに平均スピンドル回転 数の上昇, 糸切率の低下をねらったものがチェース変速 の目的である. ベース変速の効果は精紡機の高速化が進 められてきたこんにち非常に大きいことは明らかなの で, ここではチェース変速の最大効果を゙求めるべくチェ 一ス変速の最適条件を検討した.

\section{3. チェース変速の内容}

精紡機駆動用モータのプーリをV.P.S. (Variable Pitch Sheeve) に変え, カ厶でこのプーリ径を周期的

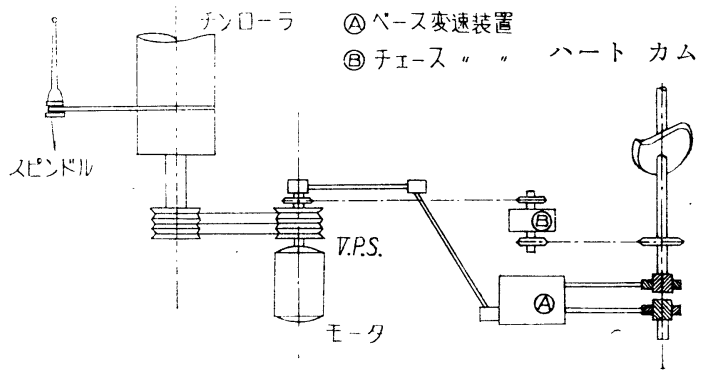

（第 2 図）精紡機自動変速装犆
(リングレール昇降周期と同じ) に変化させる。装置の 概要は第 2 凶注す。チース変速装置 (B)の内部には

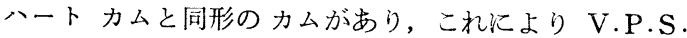
の径を周期的に変えている. (A)電気信号を5けてスピ ンドル回転を大幅に変化させるべース変速装置である. 普通は（B) 内部のチェース カムとハートカムとを同位 相にとりつけがちであるが，こ机では張力が最大になっ えときにかならずしも回転が最低になるとはかぎらな い. 張力, 回転などにつきあらかじめ充分その変化や 特性をつかんでもっとも適当な位相に取付ける必要があ り，この状態ではじめて変速装置の正しい評価ができる のである。

第 3 図に変速様式の一例を示すが，前にものべたよ5 にコップの巻きはじめに拉いては集中的糸切れが発生す ることから低速にして㧊くことがぜひ必要で, 増速後チ ェース変速を加えた形になっている，チェース変速を実 施する前にリング レール位置と張力, チェースカム信 号とスピンドル回転変化との関係を調べておく必要があ る. 第 4,5 図がこの調査結果で，これからつぎのこと
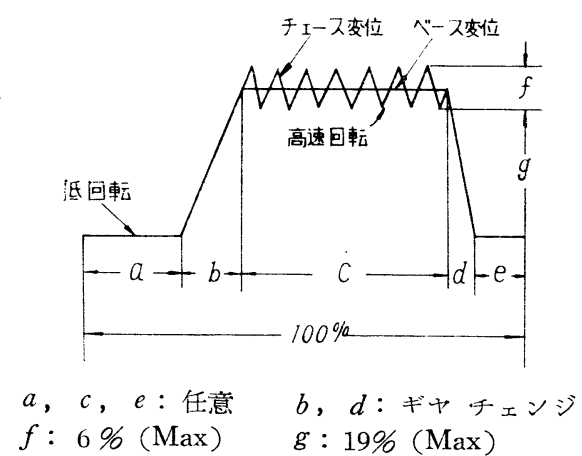

（第 3 脳）变 速 様式
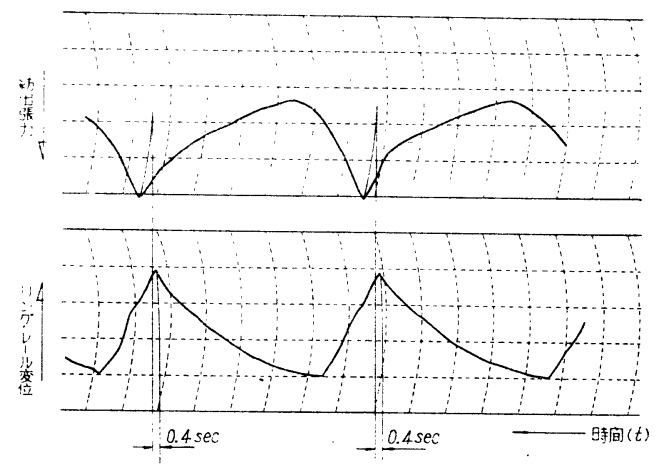

ワングレール昇降雕期 $12.4 \mathrm{sec}$ チャート送り $5 \mathrm{~mm} / \mathrm{sec}$ 回転数 (1/48 仕掛) $10700 \mathrm{rpm}$ （第4 図）リングレール变位と張力との関係 


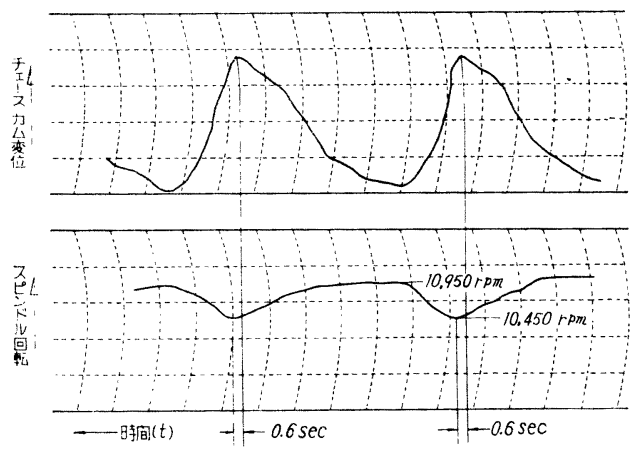

（第 5 図）チェース カム変位と回転变化との関保

が判明する.

i ) 張力のピークは巻取角最小 (リング レール最上 位置)のとさでなく、 リングレールが下降しはじめて からある時間後にあらわれる（この時間は試験を実施 した回転の範囲ではほぼ一定であった）

ii）チェースカムで変速する場合, 回転にはかなら ず時間抢くれが生ずる。

iii）回転と張力との間にも打くれのあることが判明し ている。（この括くれは前項に比較するとはるかに小さ い)

このような調查結果を考えればチェース变速中の張力 と卷取角 (リング レール位置)，スピンドル回転との関 係は第 6 四のブロック線図で示される。ここでは $L$ はり

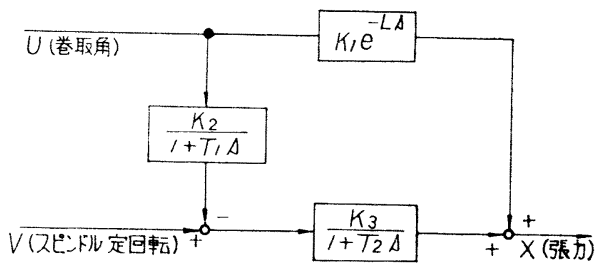

（第6刹）チェース変速を示すブロック線図

ング レール最上点と張力ピークとの時間和くれであり， 回転とチェースカムとの関係は第 5 図とモータの特性 を考慮して 1 次和くれで近似してある。な和 $T_{1} \gg T_{2}$ で あるからチェース カム信号のピークと回転最低位置と のおくれ(これを $\Delta$ とする) の計算に際しては $T_{2}$ を 無視してさしつかえない.

第6図で出力 $X$ のをできるだけ扣さえるよう最適条件をつかむ必要があ

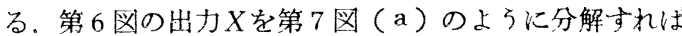
$X=X_{1}+X_{2}$ であるからXのピークの最大值は $X_{1}$ のピ 一クと $X_{2}$ の谷とが合致したときにもっとも効果的に最

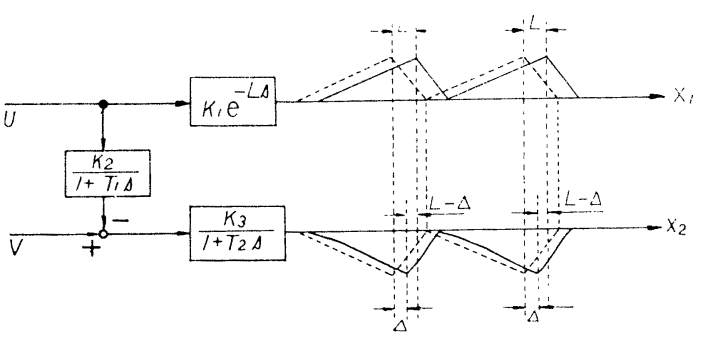

（第7図 a) 張力 分 解 図

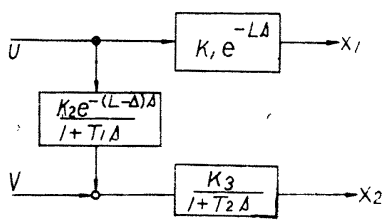

（第 7 脳 b )

大張力を扮さえることができる，糸切れは系の細い部分 において繊維が好ることであり，張力には大きな関係 はないとする報文もあるが，張力の大きいときに系切れ が生じることは第 1 図からもまたコップ巻はじめの集中 系切れからも明らかな事実であり，上にのべた最適条件 をつかめば系切率低減の期待がもてるわけである．第 7 図で $L-\Delta=0$ となるように調節できればよいわけで， このために $X_{2}$ までの間にむだ時間を入れると第 7 図 （b）のよ5になる.この調節はチェース变速用カムの 取付角度を变更することで簡単に実施でき， $\Delta>L$ の場 合はむだ時間でなく進み時間となるがカムの取付角度の ことであるから進み時間の調節も可能であり, フィード バックコントロールではこれが実施困難である。第 4 , 5 図の場合は $L-\Delta=-0.2 \mathrm{sec}$ であり, リング レール

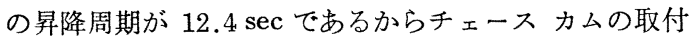
角度を $-0.2 / 12.4 \times 360^{\circ} \fallingdotseq ー 6^{\circ}$ だけ打くらせ朴ばなら ない（6 $6^{\circ}$ 取付角度を進めることと同じである）

そ毛精紡機では仕掛品種の変動がはげしく，そのたび に回転数をかえるから他の回転に和ける最適取付角度を 求めて拉く必要がある。このためにはチェースカム信 号とスピンドル回転変化との関䋆，すなわち時定数 $T_{1}$ を求めればよい。

\section{4. 最適取付角度の算出}

$T_{1}$ 算出すれば各回転数に特计る山を求めることが できる、1次打くれ要素化チェースカム信号を加えた 場合の出力を考学ればよく，したがって第 8 図（a）の ように表わすことができ，さらにチェースカムの形は 
（b）のように 3 角波形として取扱って充分である．第 8 図 $(\mathrm{b})$ の点線を時間関数 $Z(t)$ で表わすならば $Z(t)$ は周期 $t_{0}^{\prime}$ の周期関数であるからそのラプラス変換 $L$ $[Z(t)]$ は

$$
L[Z(t)]=\frac{1}{1-e^{-t_{0}^{\prime} s}} \int_{0}^{t_{0}^{\prime}} Z(t) e^{-s t} d t
$$

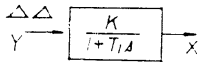

$X(\Delta)=\frac{K}{1+T / A} Y(\Delta) \cdots(1)$

(a)

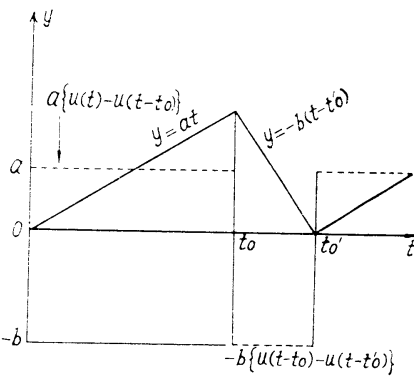

(b)
（第8図）チェース カム信号

で示される． $Z(t)$ の 1 周期をステップ関数を用いて

$$
Z(t)=a\left\{u(t)-u\left(t-t_{0}\right)\right\}-b\left\{u\left(t-t_{0}\right)-u\left(t-t_{0}^{\prime}\right)\right\}
$$

と表示し（2）式の演算を進めれば

$$
\begin{aligned}
Z(t)= & \frac{1}{1-e^{-t_{0}^{\prime} s}} \int_{0}^{t_{0}^{\prime}}\left\{a u(t)-(a+b) u\left(t-t_{0}\right)\right. \\
& \left.+b u\left(t-t_{0}^{\prime}\right)\right\} e^{-s t} d t \\
= & \frac{1}{s\left(1-e^{-t_{0}^{\prime} s}\right)}\left\{a-(a+b) e^{-t_{0} s}+b e^{-t_{0}^{\prime}}\right\}
\end{aligned}
$$

を得る、チェースカムの波形は $Z(t)$ を積分したもの であるから，チェース カム信号 (入力) のラプラス変換 $Y(s)$ は次式となる。

$$
Y(s)=\frac{1}{s^{2}\left(1-e^{\left.-t_{0}^{\prime} s\right)}\right.}\left[a-(a+b) e^{-t_{0} s}+b e^{-t_{0}^{\prime} s}\right]
$$

したがって出力 $X(s)$ は

$$
\begin{aligned}
& X(s)=\frac{K}{\left(1+T_{1} s\right) s^{2}\left(1-e^{-t_{0}^{\prime} s}\right)}[a-i a+b) e^{-t_{0} s} \\
& +b e^{-t_{0.6}^{\prime}}
\end{aligned}
$$

(6) 式の逆変換 $x(t)$ は周期関数でその 1 周期 $x_{1}(t)$ は $0 \leqq t \leqq t_{0}^{\prime}$ に批いて

$$
\begin{aligned}
& x_{1}(t)=L^{-1}\left(K\left(\frac{1}{s^{2}}-T^{1} s^{1}+\frac{T_{1}^{2}}{1+T_{1 s}}\right)\{a-\right. \\
& \left.\left.(a+b) e^{-t_{0} s}+b e^{-t_{0}^{\prime}{ }^{\prime}}\right\}\right]
\end{aligned}
$$

と表わすことができるから全時間軸についての $x(t)$ は

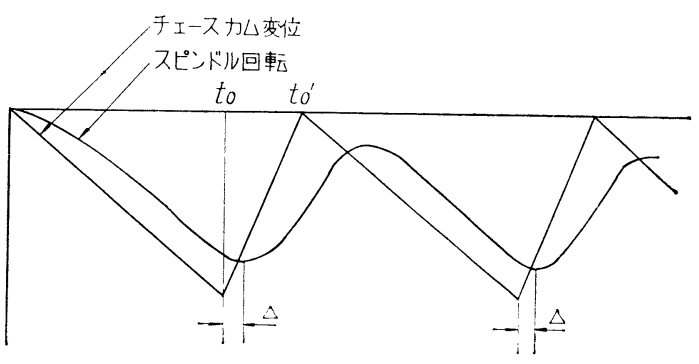

（第 9 図）チェースカム变位と回転变化（計算值）

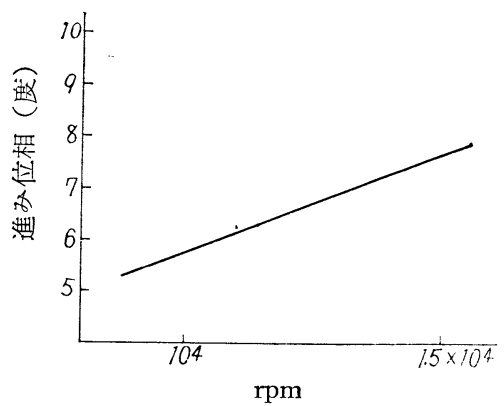

（第 10 図）各回転数に招けるカムの取付角度

容易に求まり，この結果を第 7 図に合わせて下向きに画 くと第9図のようになる。ここで 最小值を与える時間とリングレール 最上位置時との時 間差を求めて

$$
\Delta=-T_{1} \log e\{b /(a+b)\}
$$

と表わせる． $T_{1}$ はチェース変速範囲に打ける精紡機の 時定数であり， $a$ と b はそれぞれリング レールの昇降 速度である. カムの形から $b=3 a$ であり, $\Delta$ の実測值 $0.6 \mathrm{sec}$ を入れると $T_{1}=2.08 \mathrm{sec}$ を得る. $\Delta$ は (8) 式からわかるようにリング レールの昇降周期には無関 係で一定であるから各スピンドル回転に打けるチェース カムの取付角度は簡単に求められ，第 10 図の上うに線 図を作って扣けば現場汇扣いて容易汇変更することがで きる.とくに精紡機の回転をあげたときはこの取付角の 敩密な調整が必要である。

\section{5. チェース変速の効果と系切表示法}

変速装置を最適条件にセットして紡出張力をコップの 巻始めから満管まで連続記録した。この結果を第 11 図 に示す.（a）は変速運転実施前の張力変化であり，コ ップ尻が完成すると巻取角による張力変動の大きいこと がわかる．（b）は変速運転実施後のもので，チェース 変速汇上り張力変動幅が減少していることがはっきりわ かる．第 12 図に5 分玉近くでこの張力变化を拡大した 記録を示す。 


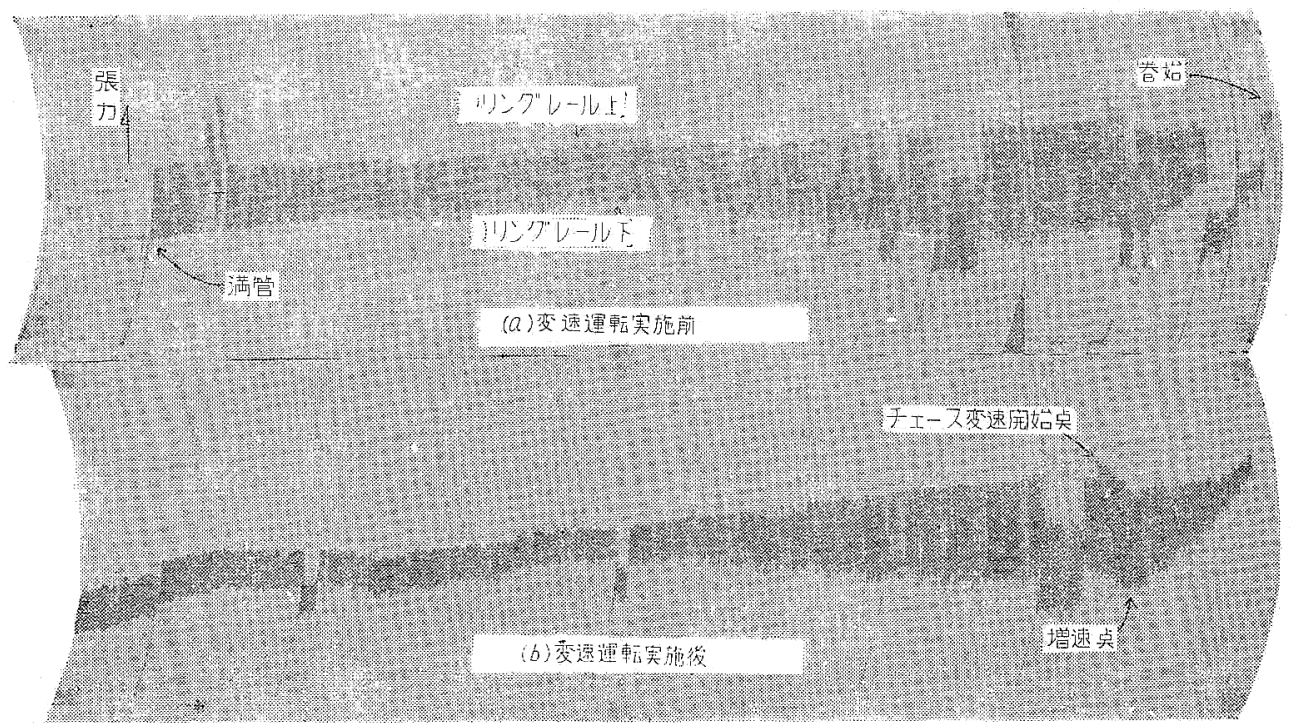

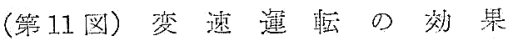

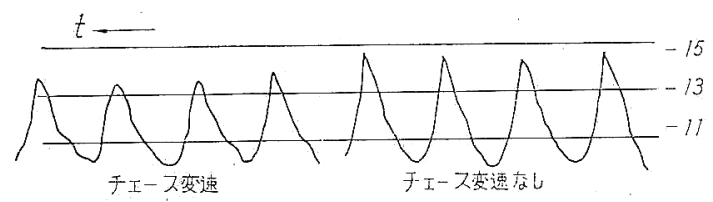

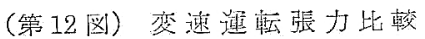

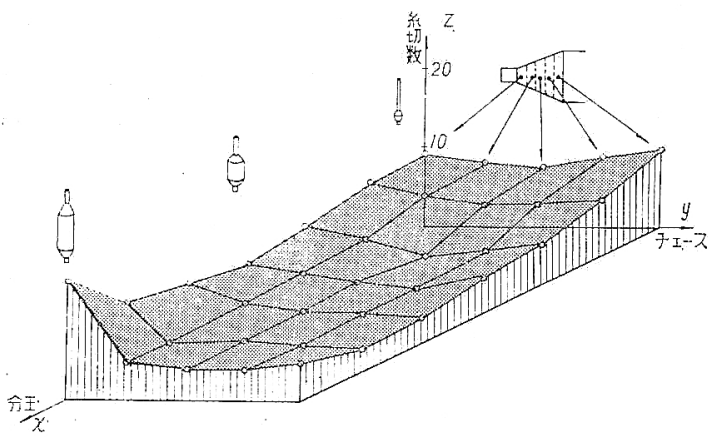

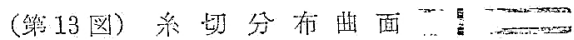

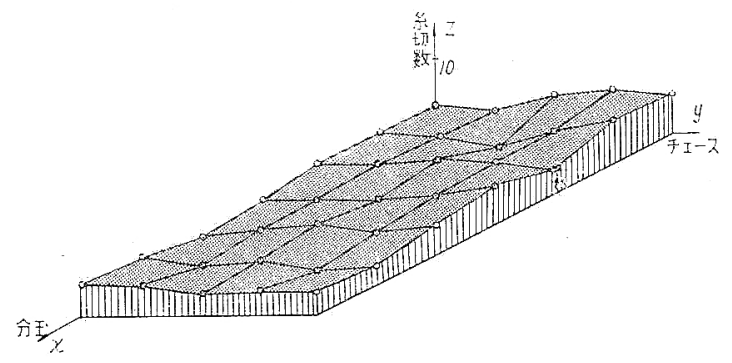

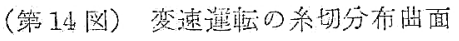

変速運転の效果は最終的火は系切机調查定施しては

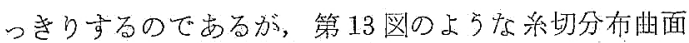
を作成すれば系切れ《ついての詳細な情報が得られる。 第 13 図恔速運転実施前の采切礼状態てdり， $x$ 軸，y 軸，z軸に各れぞれ分玉(コップ成形程度)，チェース

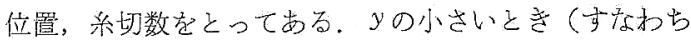
巻取角度小のとき)糸切礼が多く、チェース変速でこの

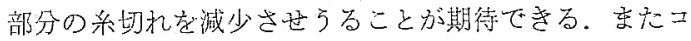
ップの巻始めにも集中的糸切れがあらわれて教り，この 什近では低速運転が望ましいことすかかる。第14図は

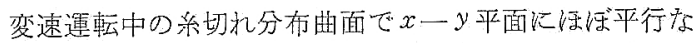
系切㣗分布曲面各得られ，集中的系切机発生はもは中生 じなくなっている。

\section{6. む す び}

ペース変速，チェース変速により条切㸉を大きく減少

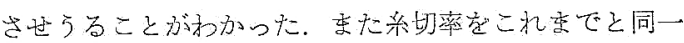
水準に软くならば平坞スピンドル回転の上昇ができる。 しかしバルーンを形成させながらの增速であるから大愊 隹回転アップを期待することはできない，われわれの経

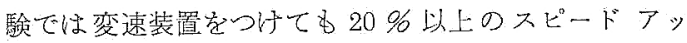
プは然理と思尗れ方。バルーンが形成されているがり 汇和いては回転がする限度以上上昇するとバルーンくず れの現象が生じる。バルーンがくずれると張打極端に 低下するのて品るが，機械の構造がこのような現象に対 しては不適当であり糸切れの原因となる。のバーン

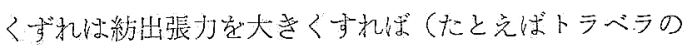


重いものにかえる）防止できるがこんどは張力が原因で 系切れが発生する。この辺に変速運転による高速化の限 界があり，大幅なスピード アップが望めない点でもあ る。この問題関しては新しい紡出法すなわちバルーン を形成させない方法に寄せる期待が大きい，これまでの 回転水準で系切率を低下せしめるには変速運転は大きな 効果がある.

以上変速運転およびその最適状態についてのべてきた が, この研究は当社岐阜工場の協力のもとに実施された
ことを最後につけくわえて拈く。

\section{文献}

1) 村上, 細辻: 精絞機紡出張力の調節, 制御工学, 5, 4, p. 27 (1961)

2) J. Adamson, C. Casswell, J. Ingham, J. B. Sharp: An investigation into the state of a worsted yarn at an end-break; J. Text. Inst., Wool Research Conference (1960) Part II, T 1131 1146. 